\title{
Opioidergic effects of transcutaneous electrical nerve stimulation on pain and inflammatory edema in a rat model of ankle sprain
}

\author{
Efeitos de opioidérgico da estimulação elétrica nervosa transcutânea sobre a dor e edema \\ inflamatório em um modelo de entorse de tornozelo em ratos \\ Efectos opioidergicos de la estimulación nerviosa eléctrica transcutánea sobre el dolor y el \\ edema inflamatorio en un modelo de rata con esguince de tobillo
}

Lívia Maria Silvestre Elisei', Julia Risso Parisi², Josie Resende Torres Silva³ ${ }^{3}$ Marcelo Lourenço Silva ${ }^{3}$

\begin{abstract}
Although transcutaneous electrical nerve stimulation (TENS) has been proposed to modulate pain and the mechanisms underlying analgesia remain poorly understood, evidence of anti-inflammatory effect is more limited. The purpose of this study was to examine the opioidergic mechanisms of TENS effects in two different frequencies on pain and inflammatory edema in the ankle sprain model in rats. Threshold to mechanical stimulation was utilized to examine the changes produced by intraperitoneal injection of non-selective opioid antagonist naloxone on the antihyperalgesic effect induced by a 20-min period of $2 \mathrm{~Hz}$ or $100 \mathrm{~Hz}$ TENS in the ankle sprain model, produced by manually overextending the lateral ligaments. Ankle sprain induced a long-lasting reduction in paw withdrawn latency (PWL) after 30 minutes for up to 24 hours in sham TENS (SH-TENS) treated rats. The reduced PWL after the induction of ankle sprain was restored partially at 0,1,2,3 and 6, but not 24 hours, after the termination of $2 \mathrm{~Hz}$ TENS (LF-TENS). In $100 \mathrm{~Hz}$ (HF-TENS) the reduction in PWL was shorter than LF-TENS and both LF and HF effects were fully blocked in naloxone-treated rats. LF- and HF-TENS treated rats did not reach the elevation of edema and presented a progressive edema reduction for over 24 hours when compared to
\end{abstract}

SH-TENS group. Both effects were reduced by naloxone. TENS-induced antihyperalgesic and anti-edematous effects observed in ankle sprain model were mediated by the endogenous opioid system.

Keywords | Transcutaneous Electric Nerve Stimulation; Ankle Injuries; Pain, Inflammation.

RESUMO | Embora estimulação elétrica nervosa transcutânea (TENS) tem sido proposta para modular a dor e os mecanismos subjacentes a analgesia permanecem mal compreendidos, evidências do efeito anti-inflamatório são mais limitadas. O objetivo deste estudo foi examinar os mecanismos opioidérgicos de efeitos de TENS em duas frequências diferentes sobre dor e edema inflamatório no modelo de entorse de tornozelo em ratos. Limiar de estimulação mecânica foi utilizado para examinar as alterações produzidas pela injeção intraperitoneal de naloxona, um antagonista opioide não-seletivo, sobre o efeito anti-hiperalgésico induzido por um período de $20 \mathrm{~min}$ de $2 \mathrm{~Hz}$ ou $100 \mathrm{~Hz}$ de TENS no modelo de entorse de tornozelo, produzido ultrapassando manualmente os ligamentos laterais. Entorse de tornozelo induziu uma redução duradoura na latência de retirada da pata (PWL) depois de 30 minutos até 24 horas em ratos tratados para TENS "simulada" (SH-TENS). A PWL reduzida após a indução

\footnotetext{
Study developed at the Universidade Federal de Alfenas (UNIFAL) - Alfenas (MG), Brazil.

'Physical Therapy Student, Universidade Federal de Alfenas - Alfenas (MG), Brazil.

2Physical therapist, Master of Science in Biosciences Applied to Health (PPGB), Universidade Federal de Alfenas - Alfenas (MG), Brazil. ${ }^{3}$ Physical therapist, PhD, professor in the Undergraduate Program in Physical Therapy and professor and advisor in the Master's in Sciences and PhD in Biosciences Applied to Health (PPGB) Universidade Federal de Alfenas - Alfenas (MG), Brazil.
} 
de entorse de tornozelo foi restaurada parcialmente em 0,1,2,3 e 6, mas não em 24 horas, após o término do 2 Hz-TENS (LFTENS). Em $100 \mathrm{~Hz}$ (HF-TENS) a redução de PWL foi menor do que LF-TENS e tanto os efeitos HF e LF foram totalmente bloqueados em ratos tratados com naloxona. Ratos tratados com LF- e HF-TENS não alcançou a elevação do edema e apresentaram uma redução progressiva do edema por mais de 24 horas, quando comparado ao grupo SH-TENS. Ambos os efeitos foram reduzidos pela naloxona. Efeitos antihiperalgésicos induzidos por TENS e efeitos antiedematosos observados no modelo de entorse de tornozelo foram mediados pelo sistema de opioides endógenos.

Descritores | Estimulação Elétrica Nervosa Transcutânea; Traumatismos do Tornozelo; Dor, Inflamação.

RESUMEN I Aunque la estimulación nerviosa eléctrica transcutánea (TENS) ha sido propuesta para modular el dolor y los mecanismos subyacentes a la analgesia sigue siendo mal entendida, la evidencia del efecto antiinflamatorio es limitada. El propósito de este estudio fue examinar los mecanismos opioidérgicos de los efectos de la TENS en dos frecuencias diferentes sobre el dolor y el edema inflamatorio en un modelo de ratas con esguince de tobillo. Se utilizó el umbral a la estimulación mecánica para examinar los cambios producidos por inyección intraperitoneal del antagonista opiáceo no selectivo naloxona sobre el efecto antihiperalgésico inducido por un período de 20 minutos de $2 \mathrm{~Hz} \mathrm{o} 100 \mathrm{~Hz}$ TENS en el modelo con esguince de tobillo, producido por sobrecarga manual de los ligamentos laterales. El esguince de tobillo indujo una reducción de larga duración en latencia de la pata retraída ( $P W L$ ) después de 30 minutos por hasta 24 horas en simulación de la TENS (SH-TENS) para las ratas tratadas. El PWL reducido después de la inducción del esguince de tobillo fue restaurado parcialmente en 0,1,2,3 y 6, pero no por 24 horas, después de la terminación de 2 Hz-TENS (LF-TENS). La reducción en PWL fue menor que LF-TENS en $100 \mathrm{~Hz}$ (HF-TENS) y tanto los efectos de LF como de HF fueron completamente bloqueados en ratas tratadas con naloxona. Las ratas tratadas con LF- y HF-TENS no alcanzaron la elevación del edema y presentaron una reducción progresiva del edema durante más de 24 horas en comparación con el grupo SH-TENS. Ambos efectos fueron reducidos por la naloxona. Efectos antihiperalgésicos y antiedematosos TENSinducidos observados en el modelo con esguince de tobillo fueron mediados por el sistema opioide endógeno.

Palabras clave | Estimulación Eléctrica Transcutánea del Nervio; Traumatismos del Tobillo; Dolor; Inflamación.

\section{INTRODUCTION}

Transcutaneous electrical nerve stimulation (TENS) is a noninvasive treatment commonly used to manage pain. While strongly supporting an analgesic effect on pain thresholds ${ }^{1-5}$, evidence of anti-inflammatory effect of TENS is more limited.

Two different theories have been proposed to explain TENS-induced analgesia. First, the gate control theory of pain ${ }^{6,7}$ proposed that the stimulation of large-diameter afferent fibers inhibits second order neurons in the dorsal horn and prevents pain impulses carried by smalldiameter fibers from reaching higher brain centers. Second, TENS activates pain inhibitory pathways stimulating the release of endogenous opioids ${ }^{8}$ and serotonin ${ }^{9}$. Endogenous opioid peptides such as betaendorphin activate opioid receptors both at the level of the spinal cord ${ }^{10,11}$ and on peripheral sensory neurons at the site of inflammation ${ }^{12,13}$. In inflammatory pain model in rats serotonin also contributes to TENS-induced analgesia via spinal $5-\mathrm{HT}_{2 \mathrm{~A}}$ and $5-\mathrm{HT}_{3}$, but not $5-\mathrm{HT}_{1 \mathrm{~A}}$ receptors and $5-\mathrm{HT}_{3}$ receptors involves GABAergic, enkephalinergic, and other classes of spinal intrinsic neurons related to gate control and descendent pain inhibitory pathways ${ }^{14}$.

The spinal cord is also involved in the modulation of peripheral inflammatory edema ${ }^{15,16}$. The spinal segmental modulation of dorsal root reflex generation seems to be the main responsible for peripheral control of the neurogenic component of inflammation ${ }^{17}$. Recently, it was demonstrated that TENS could suppress the spinal release of substance $\mathrm{P}$ and proinflammatory cytokines ${ }^{18}$. Although, TENS has proved to be an effective therapy against several pain conditions, few studies have shown that TENS can modulate or suppress the inflammatory edema.

Thus, the purpose of this study was to examine the opioidergic mechanisms of TENS effects in two different frequencies on pain and inflammatory edema in ankle sprain model in rats. 


\section{METHODOLOGY}

\section{Animals}

The experiments were conducted using male Wistar rats $(200-250 \mathrm{~g})$ from the main animal house of the Universidade Federal de Alfenas (Unifal-MG). Animals were housed at a controlled temperature $\left(24 \pm 2^{\circ} \mathrm{C}\right)$ and on a 12 -hour light-dark cycle (dark cycle beginning at $7 \mathrm{am}$ ), and they had free access to food and water. The experiments were approved by Ethics Committee (CEUA Unifal-MG, protocol 591/2014).

\section{Procedure for ankle sprain}

The rats were anesthetized with isoflurane vaporized in air (3\% for induction and 2.0\% for maintenance). Ankle sprain was produced by manually overextending the lateral ligaments by the same person, without breaking them, to imitate a lateral ankle sprain in a human ${ }^{19,20}$. Anesthesia was discontinued and the rats recovered from anesthesia within 5-10 minutes. A single operator performed this procedure to guarantee the same strength of the procedures.

\section{Inflammatory edema}

Paw edema was measured with a plethysmometer (Model 7140, Ugo Basile, Rome, Italy). Briefly, the paw is inserted into water, contained in a special water cell whose resistance is changed due to the immersion of the animals' paws. This resistance change is calibrated in $\mathrm{ml}$ and shown on the electronic monitor ${ }^{21}$. After determination of the basal volume, the animals ( $\mathrm{n}=6$ per group) were divided into experimental groups in such a way that the mean volumes of the different groups were similar. The paw volume was measured 0,1,2,3,6 and $24 \mathrm{~h}$ after TENS or sham treatment.

\section{Paw mechanical sensitivity}

Mechanical sensitivity was measured using an electronic von Frey device (Insight Equipamentos, Ribeirão Preto, SP, Brazil). Briefly, a pressure-meter which consisted of a hand-held force transducer fitted with a $0.5 \mathrm{~mm}^{2}$ polypropylene tip was applied perpendicularly to the central area of the hindpaw with a gradual increase in pressure ${ }^{22}$. The corresponding force was recorded (in grams). The smaller the force applied for inducing paw withdrawal, the more sensitive the animals were to the nociception stimulus.

\section{Drug treatment}

To evaluate the possible involvement of opioidergic mechanisms in antinociceptive effect of TENS, naloxone hydrochloride (Sigma, St. Louis, MO, USA), an opioid receptor antagonist, was dissolved in saline and injected intraperitoneally 10 minutes before the stimulation (NAL groups). Saline ( $1 \mathrm{ml}$ ) was used as control (SAL groups).

\section{TENS Treatment}

Rats were lightly anesthetized with isoflurane (2\%, 20 minutes) and TENS (Neurodyn TENS unit, IBRAMED, SP, Brazil) was applied to the ankle joint. One-inch round pregelled electrodes were placed on the medial and lateral aspects of the ankle joint (Figure 1). Sensory-intensity TENS was determined by increasing the intensity until a palpable muscle contraction was elicited and then reducing the intensity to just below that point. Rats received either 1) low-frequency TENS to the inflamed ankle joint at sensory intensity (LFTENS, 10Hz; 20 minutes); 2) high-frequency TENS at sensory intensity (HF-TENS, $100 \mathrm{~Hz} ; 20$ minutes); or 3) Sham TENS (SH-TENS, 0Hz; 20 minutes) during which the animal was placed in the same apparatus, had electrode placed but no current was applied. The pulse duration is constant at $100 \mu$ s and intensities were constant at sensory-level intensity and are based on those used clinically ${ }^{8}$.

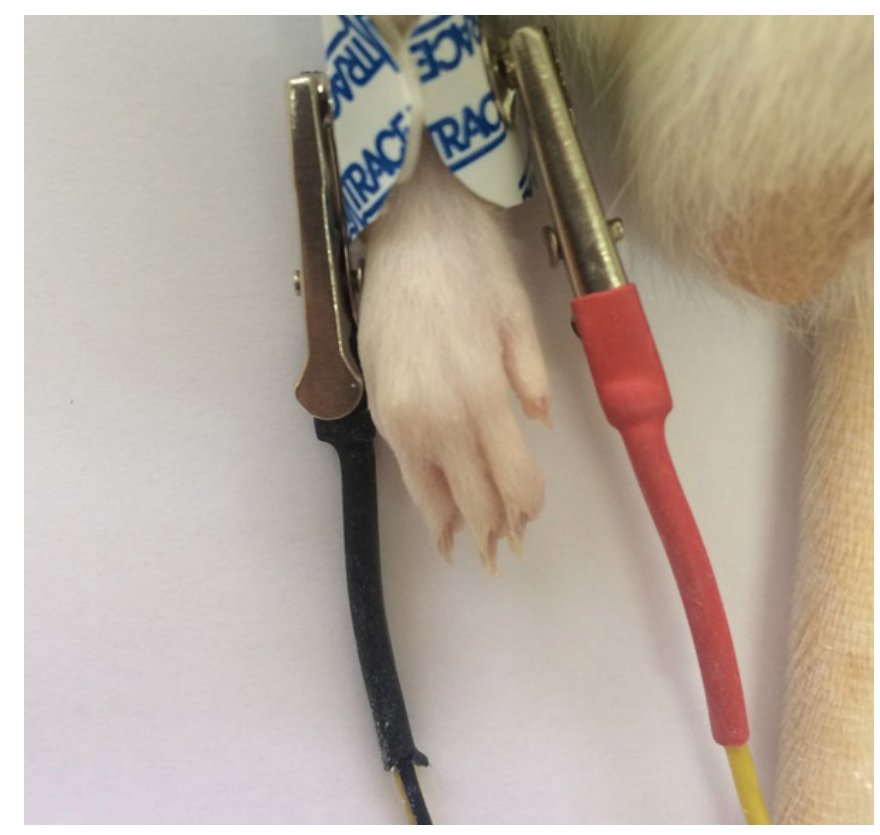

Figure 1. Electrodes placed on the medial and lateral aspects of the ankle joint. 


\section{Experimental Protocol}

Each rat was initially taken to determine its baseline PWL (baseline). The animal was then anesthetized with isoflurane and submitted to the ankle sprain procedure. PWL were again determined 30 minutes later (sprain). Saline (SAL groups, $1 \mathrm{ml}$ ) or naloxone (NAL groups, $10 \mathrm{mg} / \mathrm{kg}, 1 \mathrm{ml}$, i.p.) was injected and 10 minutes later HF-, LF- or SH-TENS were applied for 20 minutes. PWL were measured five minutes (T0), one (T1), two (T2), three (T3), six (T6) and twenty-four hours (T24) after the period of stimulation.

\section{Statistics}

Data were analyzed using the GraphPad software program Version 5.0 and expressed as the mean \pm S.E.M. Statistically significant differences between the groups were calculated using two-way analysis of variance (Anova) followed by the Newman-Keuls post-hoc test. $\mathrm{P}$-values less than 0.05 were considered significant.

\section{RESULTS}

The PWL (Figure 2) and edema (Figure 3) were measured before and after the ankle sprain. The PWL and edema baselines in each group were not different in all the experiments in the present study.

Ankle sprain induced a long-lasting reduction in PWL for up to 24 hours in SH-TENS/SAL rats (Figure 2). In this group, naloxone (SH-TENS/NAL) or saline-treated (SH-TENS/SAL) rats were not different throughout the period of observation. After the LF-TENS/SAL, the PWL was increased at 0,1,2, 3 and 6 hours, but were not different from SH-TENS/SAL after 24 hours (Figure 2A). This antinociceptive effect was fully blocked in naloxone-treated rats (LF-TENS/NAL) at all evaluated times. Similar results were obtained with HF-TENStreated rats (Figure 2B). After the HF-TENS/SAL, the PWL was increased at 0,1 and 2 hours, but were not different from SH-TENS/SAL after 3, 6 or 24 hours. This antinociceptive effect was shorter than LF-TENS/ SAL, but also fully blocked in naloxone-treated rats (HF-TENS/NAL) at all times.

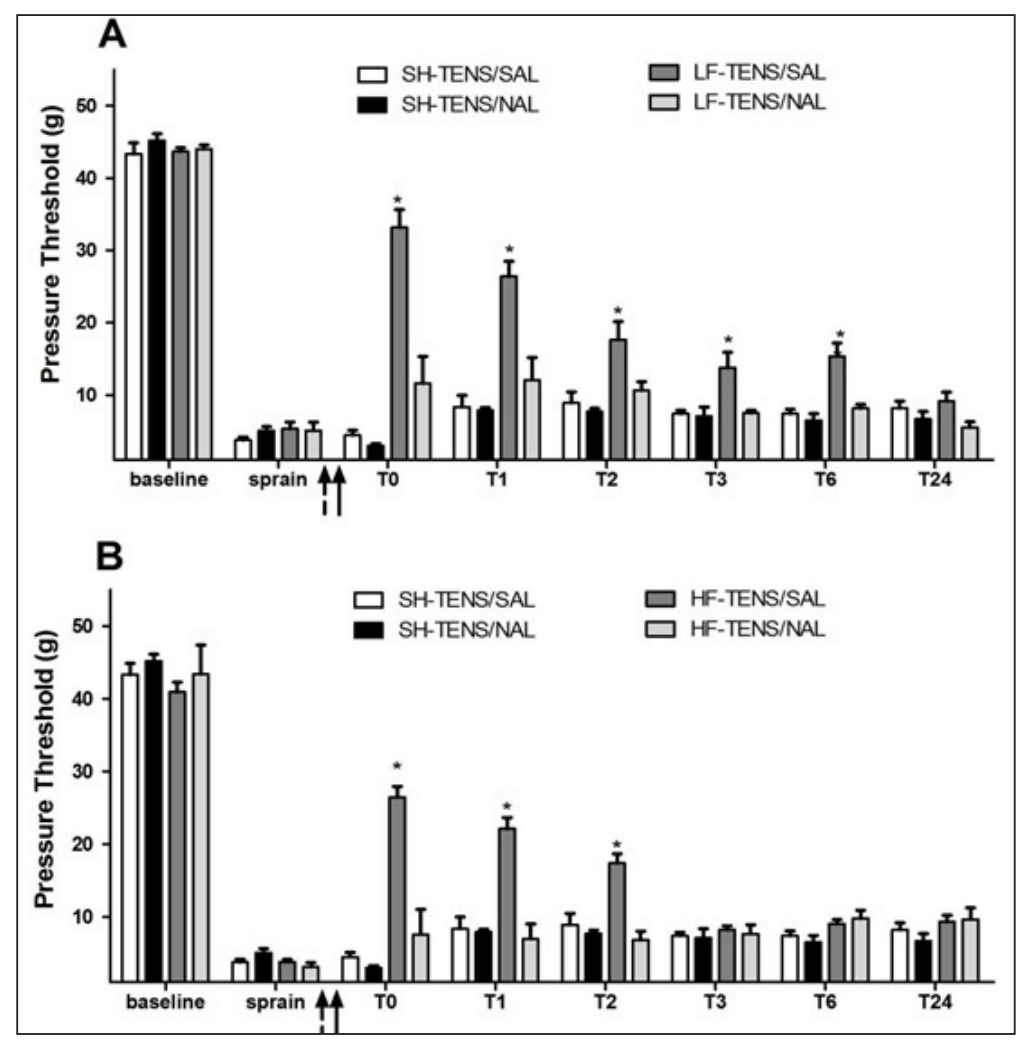

Figure 2. Effect of LF-TENS (A) or HF-TENS (B) application on sprain-induced hyperalgesia. The experiment was conducted before (baseline) and after ankle sprain (sprain) and the mechanical threshold was measured 5 min after TENS (TO) and at different times T1, T2, T3, T6 and T24 hours. The animals were pretreated (dashed arrow) with saline (SAL) or naloxone (NAL) and then 10 minutes later were treated with TENS (black arrow). Points are means \pm SD of 6 rats per group. $p<0.05$ compared with SH-TENS/SAL $(*)$. 


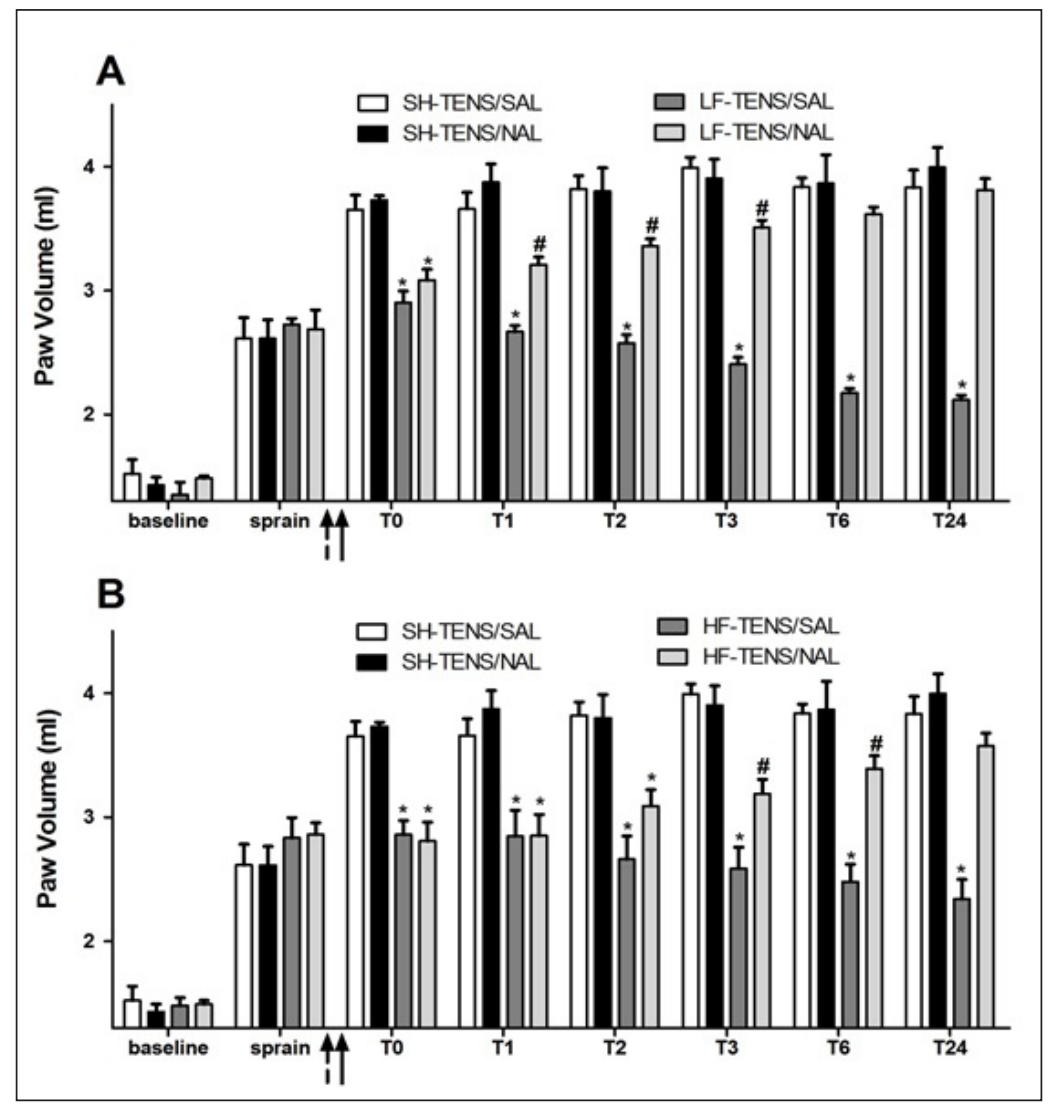

Figure 3. Effect of LF-TENS (A) or HF-TENS (B) application on sprain-induced edema. The experiment was conducted before (baseline) and after ankle sprain (sprain) and the mechanical threshold was measured 5 min after TENS (TO) and at different times T1, T2, T3, T6 and T24 hours. The animals were pretreated (dashed arrow) with saline (SAL) or naloxone (NAL) and then 10 minutes later were treated with TENS (black arrow). Points are means \pm SD of 6 rats per group. $p<0.05$ compared with SH-TENS/SAL $(*)$ or LF- or HFTENS/SAL groups (\#). The data in A were significantly different regarding treatments $(F=25,89 ; P<0.001)$, time $(F=127,11 ; P<0.001)$ and had significant treatment $x$ time interaction ( $F=8,71 ; P<0.001)$. The data in B were significantly different regarding treatments $(F=56,04 ; P<0.001)$ and were not significantly different regarding time $(F=207,55 ; P<0.001)$ or treatment $x$ time interaction $(F=13,85 ; P<0.001)$.

Before the induction of ankle sprain, the average volume of the foot was just below $2 \mathrm{ml}$ (Figure 3). The ankle swelled rapidly after the sprain induction, almost doubling its volume in after SH-TENS treatment. For this group, naloxone (SH-TENS/NAL) or salinetreated (SH-TENS/SAL) rats were not different from SH-TENS rats throughout the period of observation.

LF-TENS/SAL-treated rats had a decreased edema less intense than SH-TENS/SAL-treated rats at all times after ankle sprain (Figure 3A). This decrease in edema after LF-TENS was blocked after pre-treatment with naloxone (LF-TENS/NAL) 1 hour after the ankle sprain and maintained for 24 hours.

HF-TENS/SAL-treated rats had a decreased edema less intense than SH-TENS/SAL-treated rats at all times after ankle sprain (Figure $3 \mathrm{~B}$ ). This decrease in edema after LF-TENS was blocked after pre-treatment with naloxone (HF-TENS/NAL) 3 hours after the ankle sprain and maintained for 24 hours.

\section{DISCUSSION}

TENS has been extensively used for different purposes mainly for pain relief. However, the mechanism involved in TENS analgesic effect is not completely understood $^{23}$. In the present study, we extend these observations showing that a single session of LF-TENS or HF-TENS (10 or $100 \mathrm{~Hz}$ ) produced long-lasting reduction in mechanical inflammatory hyperalgesia and edema induced by ankle sprain in rat hind paw.

TENS effects depend on activation of opioid receptors by endogenously released opioids ${ }^{8}$. In fact, the participation of endogenous opioids on the effect of TENS, including endomorphin, endorphin, enkephalin 
and dynorphin, has been extensively described ${ }^{24}$.TENSstimulated opioids can reduce the activity of nociceptive neurons and the release of important neurotransmitters, such as substance $P$, which are involved in the transmission of nociceptive information ${ }^{18}$.

In the present study, we show that endogenous opioids are involved in the antinociceptive effect of TENS against inflammatory pain evoked by ankle sprain. The opioids released can counteract the migration of neutrophils to the site of inflammation and this effect might account for the effect of TENS against hyperalgesia and edema. The migration of neutrophils to the inflammatory site is a crucial step in the development of inflammatory hyperalgesia ${ }^{22}$.

An important question point emerging from these results is the local from where opioids are released by TENS stimulation. There is evidence that opioids can be released through the entire nociceptive system, including peripherally, in the spinal cord and supraspinal sites ${ }^{25}$.

In the periphery, two different mechanisms may result in a decreased nociception. First, opiate agonists may act directly on opioid receptors of primary afferent neurons $\mathrm{s}^{26,27}$. It has been shown that peripheral opioid receptors of primary afferents may be physiologically important because they may represent targets for endogenous opioids released during inflammatory process ${ }^{26}$.

Second, opioids can reduce inflammation through actions on leukocytes ${ }^{28}$. Numerous leukocytes, including lymphocytes, macrophages, monocytes, and polymorphonuclear cells such as neutrophils have been reported to express opioid receptors ${ }^{29}$. Direct activation of opioid receptor reduced neutrophil migration toward the inflammatory site ${ }^{30}$. In TENS effect opioid might be affecting several steps involved in neutrophil migration such as neutrophil adhesion by reducing adhesion molecules expression, chemokines-induced neutrophil chemotaxis and edema ${ }^{31}$.

TENS can also stimulate the release of opioids in the spinal dorsal horn where they exhibit inhibitory actions against excitatory transmission ${ }^{24}$. The mechanisms activated by TENS differ according to the frequency of stimulation. Low-frequency TENS $(2-10 \mathrm{~Hz})$ increases the spinal release of met-enkephalin, endomorphin and beta-endorphins, whereas high-frequency TENS $(50-100 \mathrm{~Hz})$ increases the spinal release of dynorphin and both activate pain inhibitory pathways ${ }^{24,32}$ that are represented by serotonergic and noradrenergic fibers from rostral ventromedial medulla ${ }^{33}$. This central mechanism might be involved in the TENS effect against inflammatory edema.

In summary, using the ankle sprain model, an effect of TENS was demonstrated on hyperalgesia and edema. The effect lasted for several hours and is different when compared LF-TENS higher than HFTENS. For the first time, an effect of TENS against inflammatory edema was demonstrated. Furthermore, the TENS-induced analgesia observed was mediated by the endogenous opioid system and opioids are involved in effect of TENS against inflammatory edema. These results suggest that the antihyperalgesic action of TENS might be triggered by a peripheral and/or central-acting opioid mechanism.

\section{ACKNOWLEDGEMENTS}

We are grateful for the excellent technical support of Luciana Costa Teodoro and Zélia de Fátima Fernandes. We would also like to acknowledge the help of Prof. Dr. Wiliam Alves do Prado.

\section{REFERENCES}

1. Chesterton LS, Foster NE, Wright CC, Baxter DG, Barlas P. Effects of TENS frequency, intensity and stimulation site parameter manipulation on pressure pain thresholds in healthy human subjects. Pain. 2003;106(1-2):73-80. doi: 10.1016/S0304-3959(03)00292-6.

2. Ellrich J, Lamp S. Peripheral nerve stimulation inhibits nociceptive processing: an electrophysiological study in healthy volunteers. Neuromodulation. 2005;8(4):225-32. doi: 10.1111/j.1525-1403.2005.00029.x.

3. Krabbenbos IP, Brandsma D, van Swol CF, Boezeman EH, Tromp SC, Nijhuis HJ, et al. Inhibition of cortical laserevoked potentials by transcutaneous electrical nerve stimulation. Neuromodulation. 2009;12(2):141-5. doi: 10.1111/j.1525-1403.2009.00204.x.

4. Ristić D, Spangenberg P, Ellrich J. Analgesic and antinociceptive effects of peripheral nerve neurostimulation in an advanced human experimental model. Eur J Pain. 2008;12(4):480-90. doi: 10.1016/j.ejpain.2007.07.013.

5. Vassal F, Créac'h C, Convers P, Laurent B, Garcia-Larrea L, Peyron R. Modulation of laser-evoked potentials and pain perception by Transcutaneous Electrical Nerve Stimulation (TENS): a placebo-controlled study in healthy volunteers. Clin Neurophysiol. 2013:124(9):1861-7. doi: 10.1016/j. clinph.2013.04.001.

6. Garrison DW, Foreman RD. Effects of Transcutaneous Electrical Nerve Stimulation (TENS) electrode placement on spontaneous and noxiously evoked dorsal horn cell 
activity in the cat. Neuromodulation. 2002;5(4):231-7. doi: 10.1046/j.1525-1403.2002.02036.x.

7. Melzack R, Wall PD. Pain mechanisms: a new theory. Science. 1965;150(3699):971-9.

8. Sluka KA, Bailey K, Bogush J, Olson R, Ricketts A. Treatment with either high or low frequency TENS reduces the secondary hyperalgesia observed after injection of kaolin and carrageenan into the knee joint. Pain. 1998;77(1):97-102. doi: 10.1016/S0304-3959(98)00090-6.

9. Radhakrishnan R, King EW, Dickman JK, Herold CA, Johnston NF, Spurgin ML, et al. Spinal $5-\mathrm{HT}_{2}$ and $5-\mathrm{HT}_{3}$ receptors mediate low, but not high, frequency TENSinduced antihyperalgesia in rats. Pain. 2003;105(1-2):205-13. doi: 10.1016/S0304-3959(03)00207-0.

10. Zhang RX, Lao L, Wang L, Liu B, Wang X, Ren K, et al. Involvement of opioid receptors in electroacupunctureproduced anti-hyperalgesia in rats with peripheral inflammation. Brain Res. 2004;1020(1-2):12-7. doi: 10.1016/j. brainres.2004.05.067.

11. Zhang RX, Wang L, Liu B, Qiao JT, Ren K, Berman BM, et al. Mu opioid receptor-containing neurons mediate electroacupuncture-produced anti-hyperalgesia in rats with hind paw inflammation. Brain Res. 2005;1048(1-2):235-40. doi: 10.1016/j.brainres.2005.05.008.

12. Taguchi R, Taguchi T, Kitakoji H. Involvement of peripheral opioid receptors in electroacupuncture analgesia for carrageenan-induced hyperalgesia. Brain Res. 2010;1355:97103. doi: 10.1016/j.brainres.2010.08.014.

13. Wang $Y$, Hackel D, Peng F, Rittner HL. Long-term antinociception by electroacupuncture is mediated via peripheral opioid receptors in free-moving rats with inflammatory hyperalgesia. Eur J Pain. 2013;17(10):1447-57. doi: 10.1002/j.1532-2149.2013.00325.x.

14. Woolf CJ, Mitchell D, Barrett GD. Antinociceptive effect of peripheral segmental electrical stimulation in the rat. Pain. 1980;8(2):237-52. doi: 10.1016/0304-3959(88)90011-5.

15. Daher JB, de Melo MD, Tonussi CR. Evidence for a spinal serotonergic control of the peripheral inflammation in the rat. Life Sci. 2005;76(20):2349-59. doi: 10.1016/j.Ifs.2004.11.012.

16. Daher JB, Tonussi CR. A spinal mechanism for the peripheral anti-inflammatory action of indomethacin. Brain Res. 2003;962(1-2):207-12. doi:10.1016/S0006-8993(02)04056-8.

17. Willis WD Jr. Dorsal root potentials and dorsal root reflexes: a double-edged sword. Exp Brain Res. 1999;124(4):395-421.

18. Chen YW, Tzeng JI, Lin MF, Hung CH, Wang JJ. Transcutaneous electrical nerve stimulation attenuates postsurgical allodynia and suppresses spinal substance $P$ and proinflammatory cytokine release in rats. Phys Ther. 2015;95(1):76-85. doi: 10.2522/ptj.20130306.

19. Kim HY, Koo ST, Kim JH, An K, Chung K, Chung JM. Electroacupuncture analgesia in rat ankle sprain pain model: neural mechanisms. Neurol Res. 2010;32(Suppl 1):10-7. doi: 10.1179/016164109X12537002793689.

20. Koo ST, Park YI, Lim KS, Chung K, Chung JM. Acupuncture analgesia in a new rat model of ankle sprain pain. Pain. 2002;99(3):423-31. doi: 10.1016/S0304-3959(02)00164-1.

21. Brock SC, Tonussi CR. Intrathecally injected morphine inhibits inflammatory paw edema: the involvement of nitric oxide and cyclic-guanosine monophosphate. Anesth Analg. 2008;106(3):965-71. doi: 10.1213/ane.0b013e318162cebf.

22. Cunha TM, Verri WA Jr, Valerio DA, Guerrero AT, Nogueira LG, Vieira SM, et al. Role of cytokines in mediating mechanical hypernociception in a model of delayed-type hypersensitivity in mice. Eur J Pain. 2008;12(8):1059-68. doi: 10.1016/j.ejpain.2008.02.003.

23. Bennett MI, Hughes N, Johnson MI. Methodological quality in randomised controlled trials of transcutaneous electric nerve stimulation for pain: low fidelity may explain negative findings. Pain. 2011;152(6):1226-32. doi: 10.1016/j.pain.2010.12.009.

24. Sluka KA, Walsh D. Transcutaneous electrical nerve stimulation: basic science mechanisms and clinical effectiveness. J Pain. 2003;4(3):109-21. doi: 10.1054/ jpai.2003.434.

25. Millan MJ. Descending control of pain. Prog Neurobiol. 2002;66(6):355-474. doi: 10.1016/S0301-0082(02)00009-6.

26. Cunha TM, Roman-Campos D, Lotufo CM, Duarte HL, Souza GR, Verri WA Jr, et al. Morphine peripheral analgesia depends on activation of the PI3Kgamma/AKT/nNOS/ NO/KATP signaling pathway. Proc Natl Acad Sci U S A. 2010;107(9):4442-7. doi: 10.1073/pnas.0914733107.

27. Fields HL, Emson PC, Leigh BK, Gilbert RF, Iversen LL. Multiple opiate receptor sites on primary afferent fibres. Nature. 1980;284(5754):351-3. doi: 10.1038/284351a0.

28. Wybran J. Enkephalins and endorphins as modifiers of the immune system: present and future. Fed Proc. 1985;44(1 Pt 1):92-4.

29. Carr DJ, DeCosta BR, Kim CH, Jacobson AE, Guarcello V, Rice KC, et al. Opioid receptors on cells of the immune system: evidence for delta- and kappa-classes. J Endocrinol. 1989;122(1):161-8.

30. Kapitzke D, Vetter I, Cabot PJ. Endogenous opioid analgesia in peripheral tissues and the clinical implications for pain control. Ther Clin Risk Manag. 2005;1(4):279-97.

31. Kulkarni-Narla A, Walcheck B, Brown DR. Opioid receptors on bone marrow neutrophils modulate chemotaxis and CD11b/ CD18 expression. Eur J Pharmacol. 2001;414(2-3):289-94.

32. Toda K. Response of raphe magnus neurons after acupuncture stimulation in rat. Brain Res. 1982;242(2):350-3.

33. Heinricher MM, Tavares I, Leith JL, Lumb BM. Descending control of nociception: specificity, recruitment and plasticity. Brain Res Rev. 2009;60(1):214-25. doi: 10.1016/j. brainresrev.2008.12.009. 